\title{
受容体研究と農薬科学 \#
}

昆虫のチラミン受容体 : 生物制御剤のターゲット? $\ldots \ldots \ldots \ldots \ldots \ldots \ldots \ldots \ldots \ldots \ldots \ldots \ldots$ 尾添 嘉久・太田 広人 $(267)$

担子菌（きのこ類）の交配，子実体形成にかかわるシグナルと受容体 $\ldots \ldots \ldots \ldots \ldots \ldots \ldots \ldots \ldots$ 鎌田 堯 $(272)$

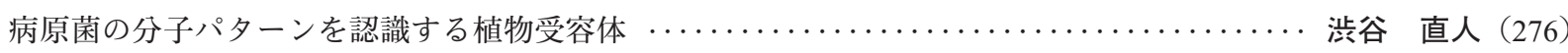

ファージディスプレイによる小分子結合ペプチドの配列および遺伝子の決定 $\ldots . \ldots \ldots \ldots \ldots \ldots$. 菅原二三男 (279)

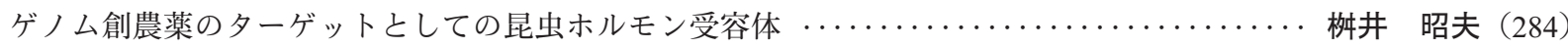

オーガナイザー: 有江 力 (東京農工大学)*

塩月 孝博（農業生物資源研究所）

このシンポジウムは日本農薬学会の学術小集会である農 薬バイオサイエンス研究会の共催によって行われた.

農薬バイオサイエンス研究会は, それぞれ日本農薬学会 の学術小集会であった農薬サイエンチスト研究会と農薬バ イオテクノロジー研究会が 2003 年 4 月に合併して新生し た。農薬サイエンチスト研究会 (1980 年発足), 農薬バイ オテクノロジー研究会（1983 年発足）が 20 余年にも亘っ て，それぞれに目指し，研究・討論を重ねてきた，「農薬サ イエンスに関する基礎的知見の集積」「「バイオテクノロジー などの新技術の利用可能性の追究」「技術の総合化」,「生 物の潜在能力の探索」「環境や安全性に関わる科学的考察」 は，作物保護ひいては食糧の確保に関する研究に新たな方 向性を与えてきた。農薬バイオサイエンス研究会は, 現在 世界的に進展しつつあるゲノムサイエンス，コンビナトリ アルケミストリーなどのダイナミックな科学にさらに柔軟 に対応できるように, また, 社会が求める安全で確実な作 物保護技術の確立にもより速やかに対応できるように, 両 研究会の伝統を継承・統合して農薬科学の発展に寄与する ことを抱負とする，そのため，本研究会は，「ポストゲノム サイエンスと作物保護研究の融合」「生物間, 生物一化合 物間相互作用の解析」,「理論に基づく新規農薬のスクリー ニング研究」「環境問題と関連した農薬代謝や安全性評価 研究」などをキーワードに, 様々な領域で活躍する研究者 に, 最先端の研究例や技術を紹介いただき, 情報交換でき る場の提供を志すこととした。

今回, 記念すべき第 1 回目の研究会を, 農薬学会大会シ ンポジゥムとして共催させていただけたことは非常に喜ば しいことである.

さて, 今回のシンポジウムのテーマは『受容体研究と農

\footnotetext{
\# 第 29 回大会シンポジウムをとりまとめた解説.

* 干 183-8509 東京都府中市幸町 3-5-8
} 東京農工大学大学院共生科学技術研究部
薬科学』とさせていただいた。農薬は, 植物をとりまく生 物間相互作用をヒトが制御するための最も一般的な手段で あり, 生物間相互作用および生物一化合物間相互作用を理 解するためには，その相互作用における認識機構の一端を 担う受容体の研究が不可欠であると考えられる. 島根大学 の尾添嘉久氏には, 昆虫の神経伝達に関与するチラミンの 受容体と結合するリガンドの探索およびチラミン受容体の 結合特性のヒト培養細胞系を利用した解析の研究結果に基 づいて, チラミン受容体の昆虫制御剂ターゲットとしての 可能性をご紹介頂いた。 岡山大学の鎌田 堯氏には, 植物 病原菌としても重要である菌類が遺伝的多様性を維持する 場と考えられている交配での相互認識（交配型が異なる株 の認識）にかかわるシグナルとその受容体に関する, 基礎 的かつ先端的な研究成果をご披露頂いた. 明治大学の渋谷 直人氏には, 植物が外来の微生物を認識して防御反応を起 こす, いわゆる獲得抵抗性の最初のステップである, 細菌 や菌類のエリシターを受容するメカニズム, さらにはそこ で受容した信号を伝達するメカニズムについて, 植物病害 防除への利用の可能性を含めてご説明頂いた，東京理科大 学の菅原二三男氏には, ゲノムデータベースが整備されつ つある現状で, ファージディスプレイ法を用いることで, 化合物とそれと結合する夕ンパク質の関係を高感度で検出 し, 植物調節剤・除草剂などの検索に利用できる可能性, 薬剤の有効性や安全性の評価に活用できる可能性について, 実例を含めてお話し頂いた。日本化薬の桝井昭夫氏は，こ れまでの生物アッセイに代わる, 理論に基づいた新規昆虫 制御剂の探索研究の例として, エクダイソン受容体をター ゲットとしたゲノム創農薬の可能性を示された。

以上 5 題のご講演の内容は, 対象生物が, 昆虫・菌類・ 細菌・植物・培養細胞まで多岐にわたっており, さらに基 礎的な研究からすぐにでも応用に結びつきそうな研究まで を含んでいたが，いずれもその分野での最先端の内容で， 俯瞰すると, 先に揭げた本研究会のキーワードをすべて網 
羅していることに気づかされる．シンポジウムをオーガナ イズさせて頂いた研究会委員の多くからも, 大変興味深く 充実していたとの感想が出されたことは特記に值する。こ 講演をいただいた 5 名の演者に，改めて厚く御礼申し上げ る。また，200 余名の方にお聴きいただいたことについて
も感謝申し上げる.

最後に，今回のシンポジウムで取り上げたような受容体 に関する研究がさらに進み, 今後農薬科学の発展に寄与す ることを期待している。

（バイオサイエンス研究会, 文責・有江 力） 